\title{
Terrorism and Counter Terrorism in Africa: A Case Study of Boko Haram and Al-Qaeda in Nigeria
}

\author{
Dr. Qudsia Akram \\ Assistant Professor \\ Department of International Relations \\ Kinnaird College for Women Lahore, Pakistan \\ qudsialakram@hotmail.com \\ Ms. Fatima Afzal \\ Undergraduate Student \\ Department of International Relations \\ Kinnaird College for Women Lahore, Pakistan \\ Ms. Arusha Siddique \\ Post - Graduate Student \\ Department of International Relations \\ Kinnaird College for Women Lahore, Pakistan
}

\begin{abstract}
Nigeria has been the victim of persistent terrorism, mostly by religious militant group's i.e, Boko Haram and Al-Qaeda. The motives of both the organizations is the implementation of Sharia law in the state and creation of an Islamic administrative structure for the purpose of which both organizations have made an alliances. This study analyzes the emergence of terrorism and subsequent counter terrorism measures taken by the state of Nigeria in response to militant terrorist organizations of Al-Qaeda and Boko haram. Initially it outlines the meaning of terrorism and the various ways in which states adopt counter terrorism measures, then specifying on Al-Qaeda and Boko haram. The origins, mechanism and reasons of these terrorist activities are scrutinized along with the protective and reactionary policies of the government in order to curb these activities and maintain state security. Examining the role of the government, state and external actors in this situation, this study concludes that peace can be achieved in the region through careful negotiations between all the




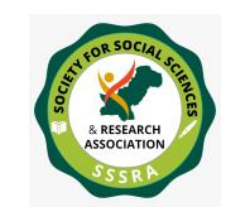

Pak. Journal of Int'L Affairs, Vol 4, Issue 3 (2021)

Terrorism and Counter Terrorism in Africa ...

parties involved with attentive care on all factors disrupting the peace process. The methodology implemented in this research is based on qualitative data, taken from primary and secondary sources to conduct the study. This study indicates that anti-terrorism policies need to be not only comprehensively added in the legislative framework rather should also be implemented effectively in order to counter terrorism within Nigeria.

\section{INTRODUCTION}

The term terrorism has been used to refer to any form of violence that creates a sense of fear among masses to gain a particular political or religious motive. Although terrorism has existed since centuries, increase in terrorist activities, globally, since 9/11 has been one of the largest international security threats. Counter terrorism initiatives by states have been taken internationally, nationally as well as regionally. Africa is one of the states where terrorism has intensified largely; primarily in the form of religious militant organizations. Africa is one of the largest continents in the world with many poor countries scattered across its region, evidently the increase in terrorism can be observed throughout Africa as a whole and could be traced to be caused by the ever growing social, political and economic problems of the states as well as due to its geostrategic location.

One such state, most affected by terrorism is Nigeria. Nigeria, a democratic secular state, is the most populous country located in the south of Africa, one of the most economically growing powerful state in the continent and an emerging power internationally at the current moment which makes it a key player in African politics. Internally, Nigeria constitutes of many ethnicities and is divided into many religious groups as well; mainly Muslims and Christians. Despite its evolving character, Nigeria has been the victim of persistent terrorism, mostly by religious militant group's i.e, Boko Haram and Al-Qaeda. The motives of both the organizations is the implementation sharia in the state and creation of an Islamic administrative structure for the purpose of which both organizations operate collaboratively, often terming Boko haram as the "representative" of Al-Qaeda in Nigeria. Since early 2000's, there has been a turbulent increase in the violent activities carried out by these organizations resulting in a grave number of deaths as well as mass movement of people. These activities not just provide a disintegrating environment for Nigeria, but have implications for Europe and the Middle East which both lie at geographical proximity to Africa which is why these attacks have called out not only national response but international alarm and resultantly international response 


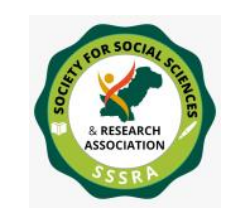

Pak. Journal of Int'L Affairs, Vol 4, Issue 3 (2021)

Terrorism and Counter Terrorism in Africa ...

as well which is crucially required to curb this terrorism, whose ideological base attracts more people and more organizations towards it posing a greater danger.

\section{CONCEPTUAL FRAMEWORK}

To understand completely the terrorism and counter terrorism measures taken against $\mathrm{Al}$ Qaeda and Boko Haram in Nigeria, it is initially critical to understand the various concepts of terrorism, non- state actors and counter terrorism. below, terrorism and nonstate actors have been defined separately and a relation between both has been created, subsequent to which counter terrorism strategies, national as well as international that have been taken in this regard have been explained.

\subsection{TERRORISM}

Terrorism has various definitions, because of lack of unanimity over one definition that can include all aspects and dimensions of the word "terrorism". Since no universally agreed upon definition of terrorism exists, states and organizations define terrorism within what seems appropriate to them, consequently the actions which constitute as terrorism also vary universally. For example, in 1994, UN general assembly condemns terrorism by describing it as:

"Criminal acts intended or calculated to provoke a state of terror in the general public, a group of persons or particular persons for political purposes are in any circumstance unjustifiable. Whatever the considerations of a political, philosophical, ideological, racial, ethnic, religious or any other nature that may be invoked to justify them."

The most common type of terrorism is religious terrorism which breeds from misinterpretation of religious texts leading to religious intolerance, fundamentalism and extremism causing violence. In text, no religion is violent in nature, it is only through different interpretations that meanings are altered to fit into the paradigm of intolerance which is why the form of extremism and intolerance taken by different religious groups and also within these religious groups varies massively (M Ranstorp ,1996).

\subsection{NON-STATE ACTORS}

Non- state actors, are entities that are not states. In international relations a non -state actor can be defined as all those actors that are not states themselves, or representatives of a particular state, but perform internationally and influence the international relations. As per the definition, these actors constitute a variety of entities that vary in their structure,

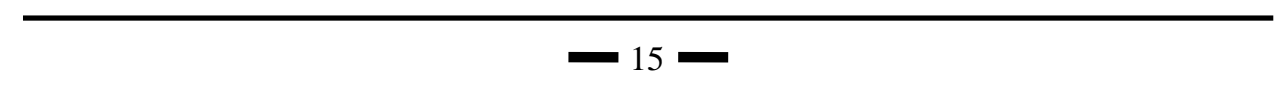




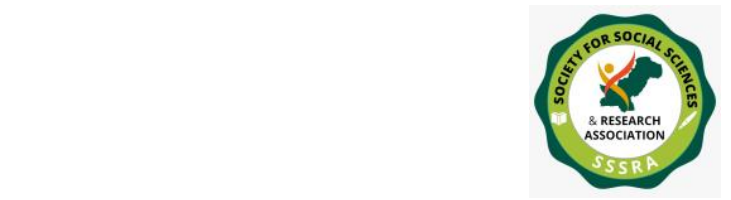

Pak. Journal of Int'L Affairs, Vol 4, Issue 3 (2021)

Terrorism and Counter Terrorism in Africa ..

objectives and level of influence they cast internationally. They may be an organization such as World Bank, may be Multi- National corporations (MNC's), violent non state actors such as drug cartels and terrorist organizations such as Islamic State of Iraq and Syria (ISIS). Although the existence of non- state actors has long been present before the cold war but with the massive proliferation of non- state actors since the cold war, states are no longer the sole entities that develop the international structure. But this does not erode the importance of states themselves. Although non-state actors have increasing importance in today's world and they may be the initiators of change, but a change in the system itself only occurs through states. Thus, states still remain the converging point of all international relations (Wendt, 1999).

\subsection{COUNTER TERRORISM}

Counter-terrorism initiatives are those measures that are taken by governments unilaterally as well as multilaterally through IGO's with the objective of protection against terrorism, as well as the offensive measures taken to retaliate in the case of occurrence of terrorist actions. But a large difference exists between counter and antiterrorism, where counter terrorism encapsulates military measures for securing against terrorist activities while the anti- terrorism encapsulates a more broad range of political, social and military offensive against the phenomena of terrorism. (Step nova, 2003).

With the launching of the war on terror by the united states of America in 2001, a global surge began that was focused upon reinforcement of global policies and strategies in regard to counter terrorism which encapsulated a broad range of initiatives by all states. These measures had a huge impact on not only the human rights agenda in the world but the securitization of states against terrorist proliferation. (Njoku, 2012)

\subsubsection{COUNTER-TERRORISM AS STATE STRATEGY AND TACTICS TO COUNTER TERRORISM}

Terrorist groups are geographically dispersed and their tactics have become more diversified. To counter terrorism, state needs a strong military, enforcement of law and intelligence communities, civilian government, private sector, strong and firm relations with other states. The most important thing among them all is coordination among different institutions of the state which includes civil society, state, private sectors, government and allies.(United Nation office of Counter terrorism,2008).To counter terrorism there is a need to adopt specific strategies, capabilities of the state must be observed and there should be some powerful allies of the state. The two most important tool that can effect to counter terrorism is cyber operation and strategic communication.

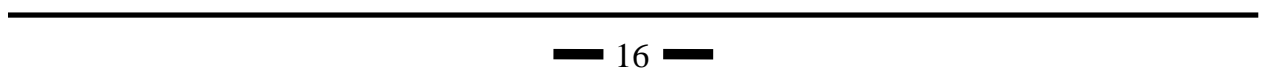




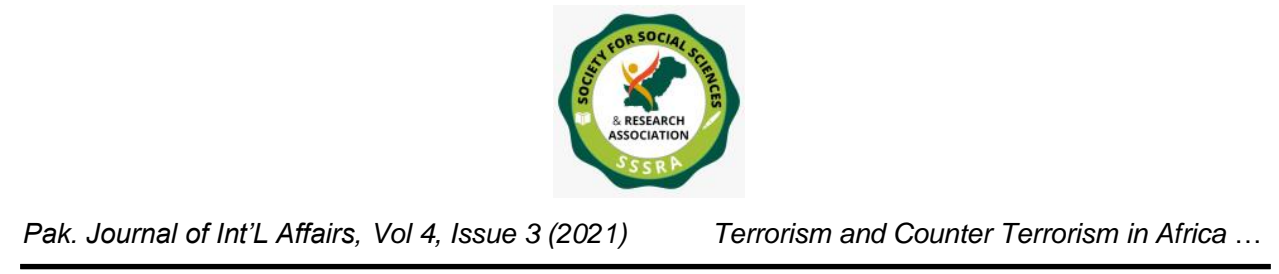

The main important thing is the availability of resources for example, Violent non-state actors are having resources to attack the states. The threats vary by region and different terrorist organizations. Countering terrorism must be balanced by state power and it must include the efforts of traditional and non-traditional partners .the main concern is to adopt domestic and foreign partners so they act for countering terrorism. Annually independent strategic reports must be prepared by researchers and intelligence so that state may get to know that how much progress they are making in countering terrorism. This will even ensure that which areas have been ignored and where they need to make adjustments in their strategy. Furthermore, There is a need to use both military and non-military ways to target terrorist groups and key terrorist which includes terrorist leaders, operational planners and individual deploying of their expertise in the areas weapon of mass destruction (WMD), cyber operations, explosives and propaganda the state needs to provide consistent economic, financial and military to disrupt the reconstitution of terrorist networks .(national strategy for counter terrorism,2018).

Counter terrorism strategies should also be strengthened internationally with consensus. The United Nations global counter terrorism strategy was initiated in the year 2006 which includes countering terrorism at state, regional and international level. Furthermore the Plan Of Action and other such initiatives are also important in the regard that the role of United Nations is highlighted through these and also measurement of human rights for all is built through state building capacities and through measures to prevent and combat terrorism.

\section{BOKO HARAM AND AL-QAEDA}

Boko Harm is a group who were used to worship at Alhaji Muhammadu Ndimi Mosque in Maiduguri and believes that there are false Muslims in Nigeria .As a result the terrorist group wants to wage the war against the false Muslims so that they can make Nigeria an Islamic state under Sharia law (John Campbell, 2014).In the year 2002 the Islamic group which was not yet known as Boko Haram called the city Maiduguri intolerably corrupt (Andrew Walker, 2012). The Islamic group moved from Maiduguri to Yobe state that was near the border of Niger where they sought to make a separate Islamic community. The group had a dispute with the police under fishing rights in a local pond in 2003 . The conflict ended as seventy members were killed including both sides which included Muhammad Ali as well (Andrew Walker, 2012). The Islamic group members who were left few returned to Maiduguri with the new leader in line known as Muhammad Yusuf (Hennery Jackson, 2014).

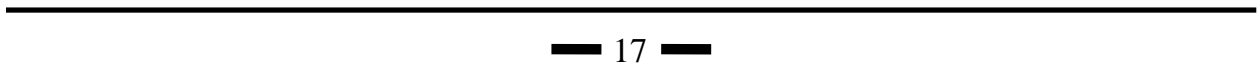




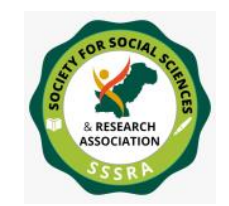

The Group expanded in to different states such as Niger, Bauchi and Maiduguri etc .The society called them as Boko Haram in Hausa language which means western education is forbidden (United states institute of peace, 2011). Boko Haram started to attack authorities, a DVD was sent to government in which he clearly threatened the state and the police authorities of Nigeria. After this event the Bauchi government arrested seven hundred members of Boko Haram and surrounded the mosque, in few days many people who were even suspected the part of Boko Haram were arrested and executed without any trial including Muhammad Yusuf the leader of Boko Haram. (Olivier Guitta, 2014) .Boko Haram has been accused of robbery in which they steal medicines and large amount of cash and claim that they do as it is written in Quran. The attacks got more intense made by Boko Haram, suicidal attacks were made in Abuja at a police station and afterwards were made on UN compound in Abuja in which 23 people were killed. This became the world news and Boko Haram was stated as an Islamic militant group.

Security intelligence states that the weapon Boko Haram has made for suicidal attack was very tough to make and the tactic Boko Haram has used for the attack clearly shows that Boko Haram was trained by a foreign hand (Stratfor, 2012). Since the year 2011 the attacks have been widened where they are attacking school and newspaper companies etc. Muhammad Yusuf stated that the purpose of Boko Haram was to make a new society in which prior or primary aim will be close to Allah and will follow the Sharia law.

The founder of Al-Qaeda is known as Osama Bin Laden. Bin Laden visited Pakistan near the borders of Afghanistan in the year 1979 during the Soviet invasion. During the war he became the donor as well to the Mujahedeen. It is stated that Mujahedeen were also getting aid from USA via Pakistan from 1981-91 of 3 billion dollars. After the end of the Soviet occupation it was sought how and what to end under which Osama Bin Laden utilized the organized group which had the size of 10,000-20,000. Where Bin Laden made the group known as Al-Qaeda where he wanted to topple the secular and proWestern Arab leaders in the year 1988..In the year 2001, 9/11 attack was made by the terrorist organization known as Al-Qaeda which moved the state (USA) and the group was known as the international terrorist organization. The master mind of the attack was Osama Bin Laden the leader of Al-Qaeda. USA after this attack set the mission of war on terror. Since the year 2001 Osama Bin Laden was the person which USA hunted for .After 10 years in searching of the most wanted criminal USA found Osama Bin laden in Pakistan and entered the state without taking permission from Pakistan. The mission took in total 45 minutes to kill Osama Bin Laden and leaving the territory Pakistan .This was against the international law but USA justified it by saying that mission had no affected the state territory (Pakistan) at all and had just targeted the terrorist leader Bin Laden not the state. 


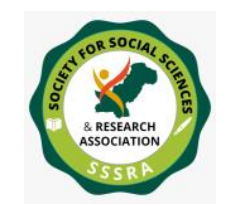

Pak. Journal of Int'L Affairs, Vol 4, Issue 3 (2021)

Terrorism and Counter Terrorism in Africa ...

\subsubsection{AL-QAEDA TIES TO BOKO HARAM}

In the year 2002 Usama Bin Laden sent 3 million dollars to Nigeria to the Salafi groups in which the main group was included of Muhammad Yusuf (Leader of Boko Haram). Al-Qaeda has the broad network under which it has been successful in making ties with Boko Haram. It is stated that members of Boko Haram get training from Al-Qaeda in Afghanistan. The providence of weapons, communication and training is made at the Arabian Peninsula in Yemen (US government, 2013). This clearly shows that Boko Haram is no longer a local terrorist group as it is clearly operating as Al-Qaeda (Good Luck Jonathan president of Nigeria). The relationship Of Al-Qaeda and Boko Haram has been matured which gives the opportunity to Boko Haram to expand in Nigeria.

\subsection{BOKO HARAM AND AL-QAEDA IN NIGERIA}

Boko Haram has been making attacks in Northern Nigeria mostly since it has come to power. The attack made in Abuja in Nigeria made it to the new level where they were known internationally. The attack was similar to Al-Qaeda which shows that both groups were affiliated with each other. The main ideology of the group is Sharia Law in Nigeria. Boko Haram means western education is sin. The only education Boko Haram agrees upon is Quran and Sunnah alternative to western and secular education which means rejection of all kind of western influence such as crime, drugs and constitutional rights of women etc. According to Boko Haram Nigeria is corrupt morally. The targets of Boko Haram includes police station, churches and government building etc. It is stated that the targets are not only Christians they are Muslims as well.

The leadership of Al-Qaeda has been weakened since the death of Osama Bin Laden. AlQaeda has the interest of making alliance with Boko Haram within the region of Africa the reason behind is that African region consists of fragile states. The same year statement was given by Boko Haram's leader that Boko Haram was the group same as Al-Qaeda with which they align and stated that the militant group Boko Haram respects Al-Qaeda. In the year 2010 the leader of Boko Haram Shekau stated on the Eid-Ul- Fitr declaration where he stated to the Muslims to make Jihad in the name of Islam against its enemies (Carter Ham, Commander of US Africa Command).

\subsection{TERRORIST STRATEGIES OF BOKO HARAM AND AL-QAEDA}

Terrorist leaders of Boko Haram and Al-Qaeda initiates motivation and establish the opportunity for the group to carry out such violent activities. It is the motivation which is the strategy of the leaders .whereas the opportunity is strategic creativity of the leader of 


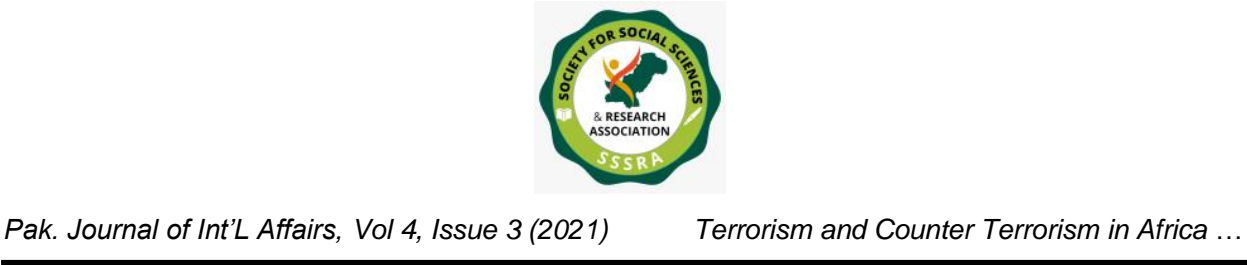

when ,how and where to conduct the terrorist attacks .Capability is based on leaders ability to initiate the process of acquiring necessary skills and resource.

\subsubsection{CENTRAL PHILOSOPHY OF BOKO HARAM AND AL-QAEDA}

Shekau portray the group (Boko Haram) as jihad group in Nigeria. Shekau explains that democracy is against Allah's laws and Nigeria has multi-party system, national anthem and national flag which should be only for Allah .According to him nation -state is the human made concept. He states that State should follow the Sharia law in moral, civil and even criminal issues.(Robin Simcox , 2013)

\subsubsection{ALLIANCES}

Boko Harm was independent group which started as a jihad group afterwards it made relations with Al-Qaeda and got financial funding from the group. (audio,2016) .Boko Haram has also managed to make alliances internally within the group. The group even used the strategy of Kidnapping to raise the funds in Borno states and in Cameroon with the help of Ansaru members (Al-Qaeda's franchise) for example Boko Haram kidnapped seven members from the French family under which they gained millions of dollars. It was the strategy of the Boko Haram leader to gain the money and wanted to negotiate with his enemies.(BBC news ,2017)

\subsubsection{STRATEGIC EMPLOYMENT OF SYMBOLS}

Shekau used the same religion and conflict symbols used by Al-Qaeda leaders where Shekau shares the same ideological belief for example he holds the weapon in his right hand same as other terrorist group leaders :Osama Bin laden .He raised his single finger where he stated about the Oneness of Allah. He even has put a moustache and a beard to portray him-self religious leader. In his videos he uses Miswak to show the Sunnah of PBUH of which he is following and the rejection of western ways which is the tooth brush.

\subsubsection{STRATEGIC LEVERAGING OF KANURI SOCIO-CULTURAL CONTEXT}

Boko Haram has carried around attacks in Lake Chad almost 90 percent .The areas which belongs to Kanem Borno Empire which is the historical place to the Kanuri people. People that belong to that area are almost illiterate and belong to the agriculture and fishing sector .The environmental change has effected them due to which unemployment has made its place in the area. The issue is that the government has

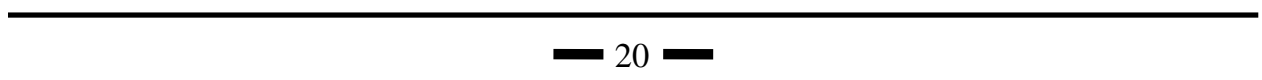




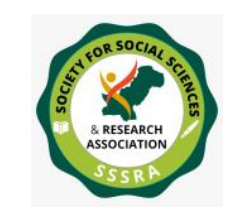

Pak. Journal of Int'L Affairs, Vol 4, Issue 3 (2021)

Terrorism and Counter Terrorism in Africa ...

neglected them where many have turned towards terrorism and organized crime. This has brought the benefit to Boko Haram where the leader have asked such unemployed people to join the group and have stated about Nigeria as a Islamic state. It is stated that almost 15000-20000 people have joined the Boko Haram group (Cameroon Defense ministry).

\section{COUNTER TERRORISM STRATEGY OF NIGERIA}

Boko Haram and Al Qaeda have expanded their control in the region of Africa so predominantly that a huge and effective control strategy is required for its management and eradication. To curb this growing conflict diplomatically, economically and militarily ,the government of Nigeria has made substantial efforts unilaterally as well as multilaterally in collaboration with other states. Terrorist organizations of Boko Haram and Al-Qaeda had evolved into a national security issue that has affected not only Nigeria but also neigbouring states. To control this excessive terrorism in the region the government of Nigeria made excessive counter terrorism strategies to control the day by day evolvement and growth of terrorist groups.

\subsubsection{NATIONAL COUNTER TERRORISM EFFORTS}

The Government of Nigeria, since the persistent attacks and focus of Boko Haram and Al Qaeda on the civilian population, has adopted a number of national policies that would help in addressing the root causes of these terrorist activities and halting their anti-state actions. Some of the initiatives taken by the government in this regard include the broad policy framework and the national action plan launched in order to provide proper supervision and direction as well as create coherence between different government authorities in order to tackle this problem effectively. Under the presidency of Muhammadu Buhari (president of Nigeria), the presidential directive to the policy framework and national action plan for preventing and countering violent extremism had been signed. Under this framework, a clear cut security agenda that rested primarily on four loci of attention was presented. These include The strengthening of the institutions of the state which would include all necessary institutions such as legislative, executive, judiciary, media, industry, NGO's etc.

The strengthening of the judicial system, access to justice for all civilians equally ; the rule of law would achieve a sovereignty that would rightfully criminalize the perpetrators of violence and injustice, The engagement of different sects of society ; participation of all stakeholders was deemed important, including the ministries, departments and agencies of the government as well as media, law enforcement, religious actors, academics and others. This would help to create a network so deeply integrated in society that the dispute could be addressed at its most fundamental level. And last but not least, 


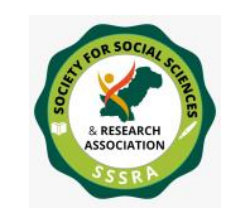

Pak. Journal of Int'L Affairs, Vol 4, Issue 3 (2021)

Terrorism and Counter Terrorism in Africa ...

the incorporation of an effective way of strategic communication in the counter terrorism program.

The Bukhari administration sought to work with local governments in order to create and develop local action plans that would be smaller versions of the national action plan for local level implementation of the program. Furthermore, another idea for dealing with the crisis was to engage in dialogue with the leadership of the terrorist group of Boko haram and offer a form of amnesty to the members of the group in return for disarmament and peaceful conditions. This use of soft power through civil society is often found extremely vital for the complete removal of the problem in many states. (Colas, 2010). For this purpose, one sect- the elites- had a tremendous hand, in lobbying the government for adoption of this step. The government has set up a 17 member committee on dialogue and peaceful resolution of security challenges in Nigeria. These steps did not achieve the perceived level of success for multiple reasons. For example, there was an increased amount of doubt and disbelief among the elites over the willingness of the government for actually solving the problem of terrorism, they were skeptical and believed that the government did not actually intend to solve the problem and were fueling the idea of Boko haram. Also, Boko haram and Al -Qaeda in itself were divided expansively over the region and contained many loose networks creating problems for the government in identifying which sub-group to start dialogue with or with whom to start negotiations.

An amendment in the legislation called The Terrorism Prevention Act (TPA) of 2011 was created in order to prevent terrorism. furthermore a revised version of NACTEST , National Counter Terrorism Strategy, was presented in 2016 and 2017. Another strategy implemented under the presidency of Bukhari was wholly focused upon the army of almajiri youth in order to educate them and raise their social status. The almajiri youth were the pupils who rose from poverty stricken homes and were highly susceptible and vulnerable to criminal tendencies during the pursuit of their education and religious empowerment. For this initiative, in 2012, the modernization of madrassa model of Almajiri Islamic education was initiated. The primary objective of this plan was to dissuade the public from the notion that westernization or western education in itself was forbidden or corrupting rather the masses were in need for perspectivization during their academic years, which was completely different and opposite to the motto of Boko haram. Although this program was set out to touch grass root level, difficulties arose with the implementation of this program which resulted in its failure. The major chunk of the national initiatives was focused upon the military counter- terrorism operations. Although these operations had begun after the creation of the Joint Task Force, which is a multinational formation comprising of the states of chad, Nigeria, Cameroon, Niger and Bennin. 


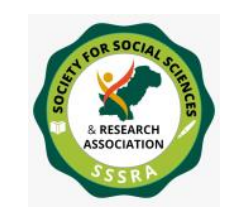

Pak. Journal of Int'L Affairs, Vol 4, Issue 3 (2021)

Terrorism and Counter Terrorism in Africa ...

A major shift towards these was found after the government of Jonathan Good luck had declared a state of emergency in the three states found geographically in the north east Nigeria, these were Adamawa, Yobe and Borno. The joint task force was although initially established to counter the threats within Nigeria solely, but eventually it became a platform for tackling cross border issues in the African region and in 2012, its mandate became inclusive of counter terrorism operations. Although Nigeria's military was successful in the peace keeping missions in Africa, while playing its part in Nigeria it proved to be incompetent and lost a large numerical proportion of its soldiers during the operations. There are a number of factors that could be reasoned in this regard including the expansive corruption in the funds and arms purchases, unpaid militia, inadequate resources and many others. The international concern arising with the worsening human rights conditions followed by these operations was also a major hindrance towards achievement of any worthwhile result since in this case because of the arms embargos placed on the country. Because of this reason the Nigerian government had to look for alternative means other than arms which they were having a very difficult time purchasing. These alternative means also included getting aid from United States of America, who has shared good relations with Nigeria and has been one of the most important trading partners of Nigeria as well.

\subsubsection{REGIONAL COUNTER TERRORISM EFFORTS}

After the attacks of September 11, On $17^{\text {th }}$ October 2001, an African summit against terrorism was held in Dakar, where the Dakar declaration against terrorism was adopted, which proposed strong condemnation of the attacks of 9/11 and voiced for making strong the 1999 African convention on the prevention and combating of terrorism through an additional protocol. African union has worked through different initiatives to tackle the problems faced by the states. In 2002, AU convened a meeting on the prevention and combating of terrorism where the plan of Action for the prevention and combating of terrorism was adopted. Among other important aspects, it calls upon member states to improve border control capability, synchronization of legislative systems, inhibit financial support to the terrorists, enhance information exchanging among states. . The peace and security council of the African union in the future devise to develop an African arrest warrant for persons who are legally found to be involved in terrorist activities. In 2004, the African Centre for the study and research on terrorism was established in Algiers, to provide training, research facilities and raw data on matters relating to terrorism which can be used by member states for future policy making and intelligence based policing approaches for the incrementally increasing terrorism. Such efforts are extremely important to help eradicate the issue of terrorism in the African region. 


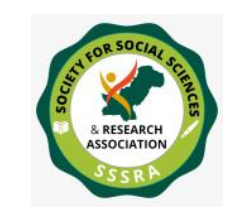

Pak. Journal of Int'L Affairs, Vol 4, Issue 3 (2021)

Terrorism and Counter Terrorism in Africa ...

\subsubsection{INTERNATIONAL COUNTER TERRORISM EFFORTS}

Terrorism is not a phenomenon which can be solved through the initiatives of one state unilaterally but rather it must be truncated through multilateral collaboration. In regards to terrorism within Nigeria, many international efforts through states, NGO's and IGO's can be seen. UNODC (United Nations office on drugs and crime) is proactive in the global war against terrorism, and has done a great amount of effort in Nigeria as well. UNODC has been supporting the Nigerian government and relevant agencies and ministries in this regard in regards to the 19 universal legal instruments against terrorism and UNSC resolutions relevant to terrorism all under the umbrella of the United Nations Global Counter-Terrorism Strategy. For this purpose, UNODC had executed 24 training sessions within Nigeria which were built around raising awareness by counter-terrorism professionals internationally, provided practical assistance for policy framing to policy makers, provided capacity building support to law enforcement officials and tried to strengthen the criminal justice response towards terrorism. Its efforts aim to increase the collaboration between different agencies on matters relating to counter- terrorism, amplify the efforts of the national legal regime in this regard, empower the aspect of humanitarian value and respect for human rights as well as give strength to the international cooperation against terrorism in Nigeria. The administration of Muhammadu Bukhari (Nigerian President), who had looked upon the crisis of terrorism as an objectively military issue, devised an approach based upon the strategies of multilateral and diplomatic help and re-structuring of the military from within (Eji, 2016). For the initial purpose, President Bukhari had made many international trips with the objective of betterment of Nigeria's international image and to gather cooperation in the counter terrorism initiative of the state. Trips made to Cameroon, and Chad were essentially focused upon strengthen the campaign against Boko haram by empowering the Multinational Joint Task Force (MNJTF), for which purpose a meeting was also held in 2015, hosted by the government of Nigeria where Nigeria's status for leading the military operations in the regard of the counter terrorism movement were agreed upon and the government of Nigeria had sided a hundred million dollars in order to reinforce and strengthen the joint military operations.

Other than these states, President Bukhari looked upon the states in the west, and engaged in this regard during the G7 meeting held in June 2015 as well as in his trip to Washington where Bukhari and Obama discussed reinforcement of the alliance of both on counter terrorism. this visit was a success and substantially enhanced US-Nigeria relations and US promised a huge sum of money for Nigeria's campaign against terrorism as well as military assistance with MNJTF and Nigeria. Another very significant step in this regard was when the government invited many western states 


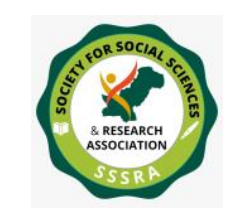

Terrorism and Counter Terrorism in Africa ...

including France, United States, United Kingdom and other Lake Chad states to an international summit in Abuja to further discuss this issue. Another military institution created in this regard is the Joint Border Task Force (JBTF) which was aided by United Kingdom, which functionalizes as an intelligence sharing organ which would disintegrate networks of criminals involved in organized crime. This framework would include multiple other British institutions as well for proper management.

The War on Terrorism can never be wholly won since it is an abstract concept, but manifestations of success can be found through the weakening of terrorist groups or decrease in either the frequency or intensity of terrorist attacks. The government of Nigeria believes that the efforts made by it have substantially weakened the terrorist groups of Boko Haram And Al Qaeda since the capacity held by the organizations to conduct attacks in the same manner have largely transformed into weaker outbursts in a relative manner (Lai Mohammed, 2015). Although weakness in the structure of the terrorist organizations has been repeatedly applauded by the Nigerian government, but gaps have been seen in this regard due to in capabilities found in Nigerian administration. For example, the agencies involved in counter terrorism do not hold the correct technical equipment or analytical expertise for data collection. Although the government is willing for collaboration with other agencies for proper effective counter terrorism measures, yet no proper and concrete results can be seen in these initiatives (Mentone, 2018). The lack of infrastructural and technical advantages reduces the government's potential for effective measures against the threat and furthermore, the high level of corruption and human rights abuse index of the state does not help in the government's authority over the subject either (Jane, 2018). it cannot be denied that the government has in fact seen a huge distinction, positive, in how Boko Haram operated before and how it does contemporarily, and that the counter terrorism efforts made by the government are in fact achieving a surmountable level of success not only by militarily weakening the organized structure of the terrorist organization but rather the psychological effect and fear inculcated within the people for these organizations has also been reduced as the masses in Nigeria now show a more liberated movement and voice within the state (Onapajo , 2017).

\section{CONCLUSION}

Boko Haram and Al-Qaeda have been the deadliest terrorist organization not only in Nigeria but in the whole region of Africa .Both (Boko Haram and Al-Qaeda) have been operating collectively in few attacks and have made alliance with each other. Al-Qaeda since the war on terrorism has lost its man power. Due to this situation in order to get powerful Al-Qaeda has been making alliance with Boko Haram and many other terrorist 


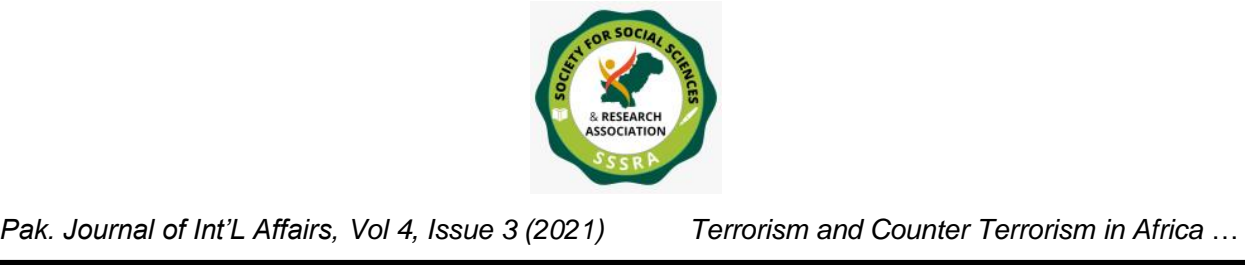

organizations . Nigerian government have been making agreements with neighboring states in African region ,Nigerian government have even discussed the case of terrorism in African Union and has been taking aid from USA . It is difficult for the third world state to completely counter terrorism in the state. The Government needs to make cooperation with Boko Haram and Al-Qaeda in order to make peace in the state and in the whole region. Terrorism in Nigeria has caused a huge issue politically and economically. It has become difficult for the state to make development economically. Nigeria is the most populous state in the African region and many people are getting less than a dollar for having food .Nigerian government due to terrorism is unable to provide basic human rights to its people.

\section{RECOMMENDATIONS}

The efforts being made for security of the state are although vast and large, complete eradication of terrorism has not been seen. To enhance their results and have a more effective system the following recommendations have been made:

- Awareness programs: the history of Nigeria is incorporated with religious extremist views, which lead to fanaticism and extremism within the masses for example the use of "jihad" as a religious salvation to justify war and warfare by book haram. Awareness programs that provide public with education and reformational thinking are important to remove previous traditional extremist views.

- Strengthening of democratic structures: the political instability in the country could be traced as the root cause of the conflict, and terrorism emerging from the grave lack of human security enforcement. Institutions promotion democracy and accountability in the state should be developed and strengthened.

- Development of cyber security policies and strategies: since the dynamic of terrorism is evolving day by day and technology has been playing such a massive role in the proliferation of terrorism, it is very important that Nigeria strengthen its cyber security and establish and implement the relevant policies and strategies required in conjunction with development of its security system. A surveillance network should be used for social media networks as well, in order to monitor the situation completely.

- Allocation of distinct and transparent counter terrorism funding: with the increase of corruption in the state, the government should adopt and enforce a more well developed counter terrorism spending budget primarily focused upon prevention, mitigation and response to terrorist attacks. 


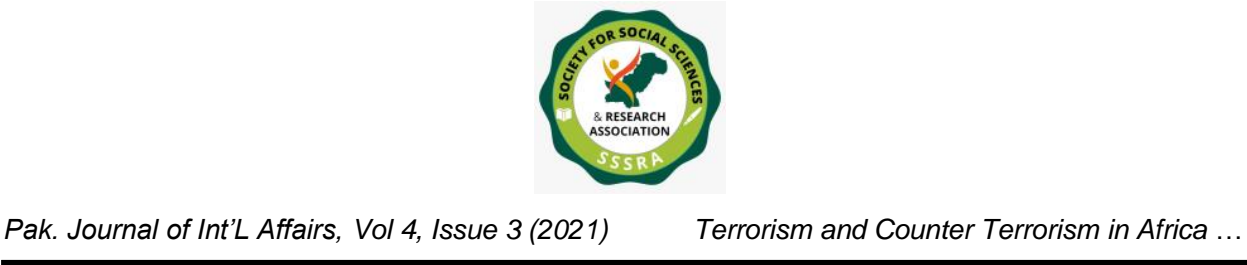

- Establishing cross border security points: Nigeria should enforce strict cross border checking of movement of people and commodities through the border provided the fluid movement of al Qaeda and Boko haram insurgents through the area's external borders.

- Creation of information exchange system: in the contemporary scenario, no proper network or infrastructure exists for communication and this has produced mismanagement and an unsecure environment where terrorists have gotten more freedom. The nation requires a safer system of communication infrastructure and a secure information channel.

- Institutional cooperation: all the institutions of the state should work collaboratively to form more connective umbrella network that would gage all aspects of the terrorism in society, including military, executive, and judicial and all others as well.

- Strengthening of the criminal justice system: arrest and prosecution of everyone involved in funding, supporting and doing terrorist activities should be ensured. A strong commitment by the government should be exhibited in order to create a sense of fear in anyone actively or passively involved in this cycle.

- Establishment of legislation relevant to the conflict: old and outdated legislation and policies hinder better management of the conflict and shortfalls such as these strengthen the grey zone where terrorism cannot be directly addressed. New legislation, with a 45 strong criminal justice capacity should be introduced to undertake rule of law based prosecutions and investigations.

- Regional and international help: a deep analysis should be made identifying the relationship between societal aspects and terrorism and they should sought to be addressed under the international norms of counter terrorism mechanism with the help of regional states as well as international organizations and states bilaterally.

- Diplomatic negotiations: the government of Nigeria should increase negotiations with terrorist organizations (Boko haram and $\mathrm{Al}$ aqeda), because countering the organizations has been inherently difficult thus forming negotiations through mediation and third party intervention or otherwise may be important. The use of United states for this mediation and intervention may be helpful, considering the alliance of both the states.

This shows that Nigeria is under developed state it needs to plan effectively and efficiently to counter terrorism (Boko Haram and Al-Qaeda). Not only this it is the responsibility of the state Nigeria to maintain peace in the territory. 


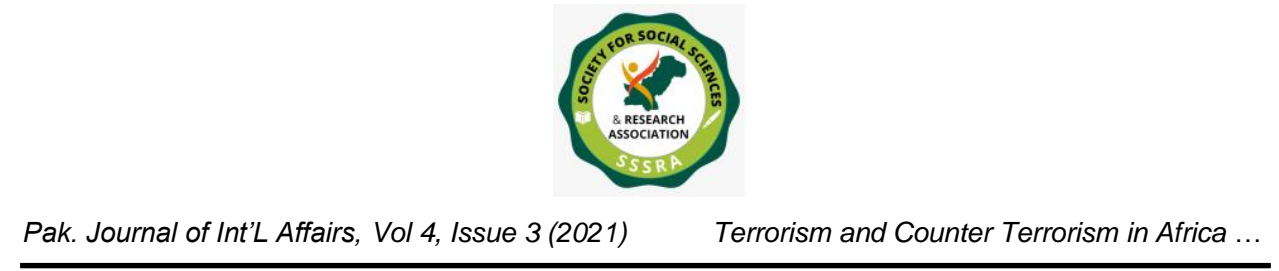

\section{References}

Abdulbasit Kassim. (2016). Boko Haram Beyond the Headlines: Analyses of Africa's Enduring Insurgency. Combating Terrorism Center at West Point United States Military Academy.https://ctc.usma.edu/app/uploads/2018/05/Boko-Haram-Beyond-theHeadlines.pdf

Abugbilla. F. M. (2017). Boko Haram and the African Union's Response, Arizona, David Campbell.https://www.davidpublisher.org/Public/uploads/Contribute/59265073cef28.pdf

Anderson, S., Peterson, M. A., Toops, S.W., \& Hey, J.A.K. (2015). International Studies: An Interdisciplinary Approach to Global Issues, Third Edition. Boulder Colorado: Westview Press.

Andrew Walker. (2012). What Is Boko Haram?. UNITED STATES INSTITUTE OF PEACE. https://www.usip.org/sites/default/files/resources/SR308.pdf

Basil. A. (2018). Boko Haram Beyond the Headlines: Analyses of Africa's Enduring Insurgency. USA, United States Military Academy the department of defense.

Blanchard L. P. and T. Cavigelli. (2018). Boko Haram and the Islamic State's West Africa Province. USA, Congressional research services.

Daniel Torbjörnsson and Michael Jonsson.(2017). Boko Haram On the verge of defeat or a long term threat?. FOIfile:///C:/Users/Core\%20i3/Downloads/FOIR4488SE.pdf

Eji, E. (2016). Rethinking Nigeria's Counter-Terrorism Strategy. The International Journal of Intelligence, Security, and Public Affairs. 18. 198-220. 10.1080/23800992.2016.1242278.

Guin,T. \& Hoffman,B. (1993). The impact of terrorism on public opinion, 1988 to 1989. RAND Publications.

Hans Krech.(2011). The Growing Influence of Al-Qaeda on the African Continent. The institute of African Affairs. https://www.researchgate.net/publication/254416467_The_Growing_Influence_of_AlQaeda_on_the_African_Continent

Henry Jackson. (2014). Terrorism in Nigeria The Threat from Boko Haram and Ansaru. The Henry Jackson Society. http://henryjacksonsociety.org/wpcontent/uploads/2014/06/Nigeria-Boko-Haram-Strategic-Briefing.pdf

Hogendoorn EJ. (2018). To Help Defeat Boko Haram, the EU Should Push for Good Governance and Accountability. Hague, International center for counter terrorism. https://icct.nl/wp-content/uploads/2018/10/ICCT-Hogendoorn-Boko-Haram-GoodGovernance-Accountability-October2018.pdf

J. Peter Pham. How Boko Haram Became The Islamic state's west Africa Province. Africa Center at the Atlantic Council . 


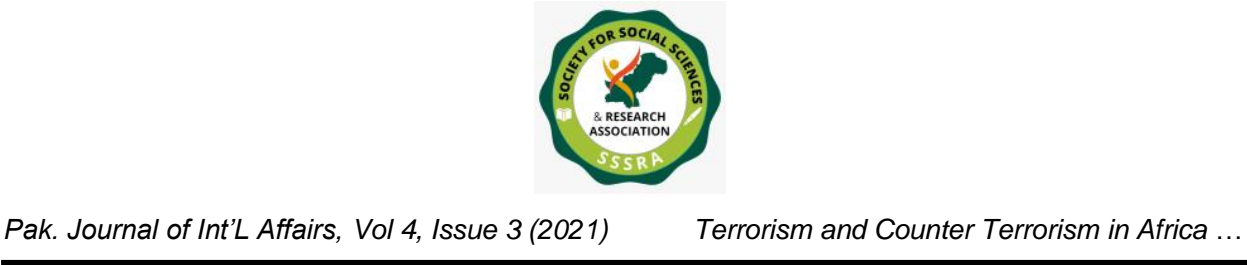

Jenkins, B. (1985). A conceptual framework for analyzing terrorist groups. RAND publications.

John Campbel.(2014). Boko Haram: origins, challenges and responses.NOREF. https://www.files.ethz.ch/isn/184795/5cf0ebc94fb36d66309681cda24664f9.pdf

John Shola .(2015). Globalization Of Terrorism: A Case Study Of Boko-Haram In Nigeria. International Journal of Politics and Good Governance.https://www.researchgate.net/publication/312525172_GLOBILIZATION_O F_TERRORISM_A_CASE_STUDY_OF_BOKO-

HARAM_IN_NIGERIA?enrichId=rgreq-60e20dacae21444b2067dd7d79ef18e5XXX\&enrichSource=Y292ZXJQYWdlOzMxMjUyNTE3MjtBUzo0NTIxODY5MjE1N DE2MzJAMTQ4NDgyMTE3MTA2Mg\%3D\%3D\&el=1_x_3\&_esc=publicationCoverPd $\mathrm{f}$

Lauren Ploch Blanchard.(2018). Boko Haram and the Islamic State's West Africa Province. In Focus.https://www.google.com/search?rlz=1C1CHBF_enPK816PK816\&sxsrf=ALeKk01 7yAbfFirHtPZhv7SoGnvJj31A\%3A1584645066073\&ei=ysNzXsz6A6TKgwfeyrqYDA $\& q=$ Boko+Haram + and + the + Islamic + State $\%$ E2\%80\%99s+West+Africa+Province+pdf + \&oq=Boko+Haram+and+the+Islamic+State $\%$ E2\%80\%99s+West+Africa+Province+pdf + \&gs_l=psy-ab.3..33i16012.2926.4185..4551...0.0..0.363.1989.2-4j3.....0....1..gwswiz.......35i39j35i302i39j33i21.W1_bxLSHY9I\&ved=0ahUKEwjMh4jynqfoAhUk5eAK HV61DsMQ4dUDCAs\&uact=5

Meierrieks, Daniel \& Krieger, Tim. (2011). What causes terrorism?. Public Choice. 147. 3-27. 10.1007/s11127-010-9601-1.

Mentone, D. (2018) . The Counterterrorism framework in Nigeria: Strategic and Operational Pitfall: European Eye on Radicalization Report. https://eeradicalization.com/thecounterterrorism-frameworkin-nigeria-strategic-and-operational-pitfalls/

Ms. Maike Knoechelmann . (2014). Why the Nigerian Counter-Terrorism policy toward

Munshi, N. (2018). Why Nigeria is Struggling to Defeat Boko Haram. Financial Times. https://www.ft.com/content/62928c8e-f7b8--11e8--8b7c-6fa24bd5409c

Nelson, J. (2006). The Business of Peace: The Private Sector as a Partner in Conflict Prevention and Resolution, London: International Alert.

Njoku, E. (2012). Terrorism and the United Nations System: The Global War on Terrorism. LAP LAMBERT academic publishing.

Nye, J. and Keohane, R. (1971). Transnational relations and world politics: a conclusion. Cambridge University Press.

O. Omale Don John. (2013). Terrorism and Counter Terrorism in Nigeria: Theoretical Paradigms and Lessons for Public Policy. Nigeria, Salem University. 
O' Bello Akeem. (2019).Countering Boko Haram insurgency: interrogating cultural destruction attempts and conservation efforts in North-East Nigeria. West Texas, University Student Research Conference.

Persson, H. (2014). Nigeria- an over view of challenges to peace and security .

Pham J. Peter. (2018). How Boko Haram Became the Islamic state's West Africa Province.UK, Countering terrorism at West Point.

Ranstorp, M. (1996). Terrorism in the name of religion. Journal of international affairs.

Soumia Ait Hida. (2016)Boko Haram And Jihad In Nigeria. Theo Brinkel and Soumia AitHida Netherlands Defence Academy, Department of International Security Studies. https://www.researchgate.net/publication/272775907_BOKO_HARAM_AND_JIHAD_I N_NIGERIA

Varin Caroline, Abu-Bakr Dauda and Macmillan Palgrave. (2017). Violent Non - State actors in Africa .USA ,Springer nature.

Walker Andrew. (2012). What Is Boko Haram? .USA ,United States Institute OF Peace Special Report.

Yinka Olomoojobi. (2011). Boko Haram: Its Terror Networks And Western Response. School of https://papers.ssrn.com/sol3/papers.cfm?abstract_id=2858585 Law \& Security Studies, Babcock University 